\title{
Immunmodulatory Treatment Strategies of Hepatocellular Carcinoma: From Checkpoint Inhibitors Now to an Integrated Approach in the Future
}

\author{
Matthias Ocker ${ }^{1,2}\left(\mathbb{D}\right.$, Christian Mayr ${ }^{3,4}$, Tobias Kiesslich ${ }^{3,4}$, Sebastian Stintzing ${ }^{5}$ and Daniel Neureiter ${ }^{6,7, *}$ \\ 1 Department of Gastroenterology (Campus Benjamin Franklin), Charité University Medicine Berlin, \\ 10117 Berlin, Germany; matthias.ocker@charite.de \\ 2 Translational Medicine \& Clinical Pharmacology, Boehringer Ingelheim Pharma GmbH \& Co. KG, \\ 55216 Ingelheim, Germany \\ 3 Institute of Physiology and Pathophysiology, Paracelsus Medical University, 5020 Salzburg, Austria; \\ christian.mayr@pmu.ac.at (C.M.); tobias.kiesslich@pmu.ac.at (T.K.) \\ 4 Department of Internal Medicine I, Paracelsus Medical University, University Hospital Salzburg (SALK), \\ 5020 Salzburg, Austria \\ 5 Division of Hematology, Oncology, and Tumor Immunology (Campus Charité Mitte), Medical Department, \\ Charité University Medicine Berlin, 10117 Berlin, Germany; sebastian.stintzing@charite.de \\ 6 Institute of Pathology, Paracelsus Medical University, University Hospital Salzburg (SALK), \\ 5020 Salzburg, Austria \\ 7 Cancer Cluster Salzburg, 5020 Salzburg, Austria \\ check for \\ * Correspondence: d.neureiter@salk.at
}

updates

Citation: Ocker, M.; Mayr, C.; Kiesslich, T.; Stintzing, S.; Neureiter, D. Immunmodulatory Treatment Strategies of Hepatocellular Carcinoma: From Checkpoint Inhibitors Now to an Integrated Approach in the Future. Cancers 2021, 13, 1558. https://doi.org/10.3390/ cancers 13071558

Academic Editors: Alessandro Vitale and Quirino Lai

Received: 25 February 2021

Accepted: 25 March 2021

Published: 29 March 2021

Publisher's Note: MDPI stays neutral with regard to jurisdictional claims in published maps and institutional affiliations.

Copyright: (c) 2021 by the authors. Licensee MDPI, Basel, Switzerland. This article is an open access article distributed under the terms and conditions of the Creative Commons Attribution (CC BY) license (https:/ / creativecommons.org/licenses/by/ $4.0 /)$.
Simple Summary: Hepatocellular carcinoma (HCC) is among the most common cancer diseases worldwide and has only limited treatment options at advanced disease stages. Activation of the immune system with checkpoint inhibitors has revolutionized cancer medicine and has become important also for HCC treatment. Here, we summarize the current status of immunotherapy options for HCC and highlight how combination with locoregional therapies could improve the outcome of patients. Novel pathways and targets for immunologic drug development are briefly discussed that could help to increase the response rate of these approaches in HCC.

Abstract: Background: Hepatocellular carcinoma (HCC) still represents a human tumor entity with very limited therapeutic options, especially for advanced stages. Here, immune checkpoint modulating drugs alone or in combination with local ablative techniques could open a new and attractive therapeutic "door" to improve outcome and response rate for patients with HCC. Methods: Published data on HCC experimental to pre-(clinical) treatment strategies from standard of care to novel immunomodulatory concepts were summarized and discussed in detail. Results: Overall, our knowledge of the role of immune checkpoints in HCC is dramatically increased in the last years. Experimental and pre-clinical findings could be translated to phase 1 and 2 clinical trials and became standard of care. Local ablative techniques of HCC could improve the effectivity of immune checkpoint inhibitors in situ. Conclusions: This review demonstrates the importance of immunomodulatory treatment strategies of HCC, whereby the "best treatment code" of immune checkpoint drugs, combination with ablative techniques and of timing must be evaluated in coming clinical trials.

Keywords: hepatocellular carcinoma; immunotherapy; immune checkpoint inhibitors; locoregional treatment

\section{Introduction}

Liver cancer represents a considerable health issue due to an increasing incidence in most regions worldwide. It accounts for about 840,000 new cases and 780,000 estimated 
deaths-ranking 6th by incidence and 4th by cancer-related mortality for both sexes [1-3]. A clear male preponderance (2-3 times higher, up to five times in some countries $[3,4])$ is reflected by the age-standardized worldwide incidence rate of 13.9 and 4.9 per 100,000 male and female inhabitants, respectively [2]. Both, incidence and mortality rates vary by region mapping to the geographical distribution of viral hepatitis $\mathrm{B} / \mathrm{C}(\mathrm{HBV} / \mathrm{HCV})$ which are the most important causes of chronic liver disease and HCC [3,5]: while the highest numbers are found in eastern Asia with incidence/mortality rates of $17.7 / 16.0$, respectively, Europe records about 4.0-6.8 new cases and 3.8-5.3 deaths from liver cancer and North America has about 6.6 new cases and 4.8 deaths per 100,000 inhabitants, for example [2]. These epidemiologic figures describe the situation for primary liver cancer which mainly compromises cases with hepatocellular carcinoma (HCC, 75-85\%), besides $10-15 \%$ cases of intrahepatic cholangiocarcinoma as well as other rare tumors [1].

Figure 1 summarizes the main risk factors for development of HCC which include $\mathrm{HBV}, \mathrm{HCV}$, excessive alcohol consumption, metabolic syndrome, type-2 diabetes, obesity, non-alcoholic fatty liver disease (NAFLD), aflatoxin $\mathrm{B}_{1}\left(\mathrm{AFB}_{1}\right)$, tobacco, dietary factors (coffee decreases while high iron intake increases the HCC risk), as well as individual genetics (e.g., mutations in genes responsible for hemochromatosis, alpha-1-antitrypsin deficiency, glycogen storage disease, porphyrias, tyrosinemia, and Wilson's disease) [3]. Accordingly, programs for prevention of HCC showed considerable efficiency, e.g., by a $80 \% / 92 \%$ reduction of HCC incidence/mortality after neonatal HBV vaccination in Taiwan [6] and a $71 \%$ reduction of HCC risk by antiviral therapy achieving sustained virological response (SVR, [7]).

As reviewed by others [5,8], surveillance for HCC is based on abdominal ultrasound and includes patients with liver cirrhosis, chronic HBV carriers or HCV-infected subjects with bridging fibrosis as well as patients with HCV infection and advanced fibrosis. Such surveillance might be supplemented in future by liquid biopsy [8-10] or other blood tests (e.g., GALAD score [11,12]). Currently, diagnosis of HCC is primarily based on imaging using computed tomography (CT) or magnetic resonance imaging (MRI) taking into account the typical vascular characteristics of HCC $[5,13]$. While the formal pathological proof is not mandatory for diagnosis of HCC, histopathological analyses by hematoxylin \& eosin (H\&E) supplemented by specific immunohistochemical analysis (IHC) allows for discrimination of HCC from benign or premalignant lesions (dysplastic nodules, hepatocellular adenoma, focal nodular hyperplasia) or intrahepatic cholangiocarcinoma (ihCC), combined HCC/CC and metastases of other primary tumors [5]. As summarized in Figure 1, confirmed cases of HCC undergo staging for optimal patient stratification and decision on subsequent therapeutic approaches: the most commonly used Barcelona Clinic Liver Cancer system $(\mathrm{BCLC})$ integrates tumor stage, liver function parameters, cancer-related symptoms and performance status and classifies HCC patients into five categories (0, A-D) [14]. While very early or early stage HCC (BCLC $0, A)$ patients are eligible for curative surgical treatment (including liver transplantation) and locoregional ablation yielding survival times of $>5$ years, BCLC B (intermediate stage) patients currently receive transarterial chemoembolisation (TACE) associated with $<2-5$ years survival. Systemic treatment with multikinase inhibitors (e.g., sorafenib) in patients at BCLC stage C (advanced) usually achieves survival times of up to one year [14]. 


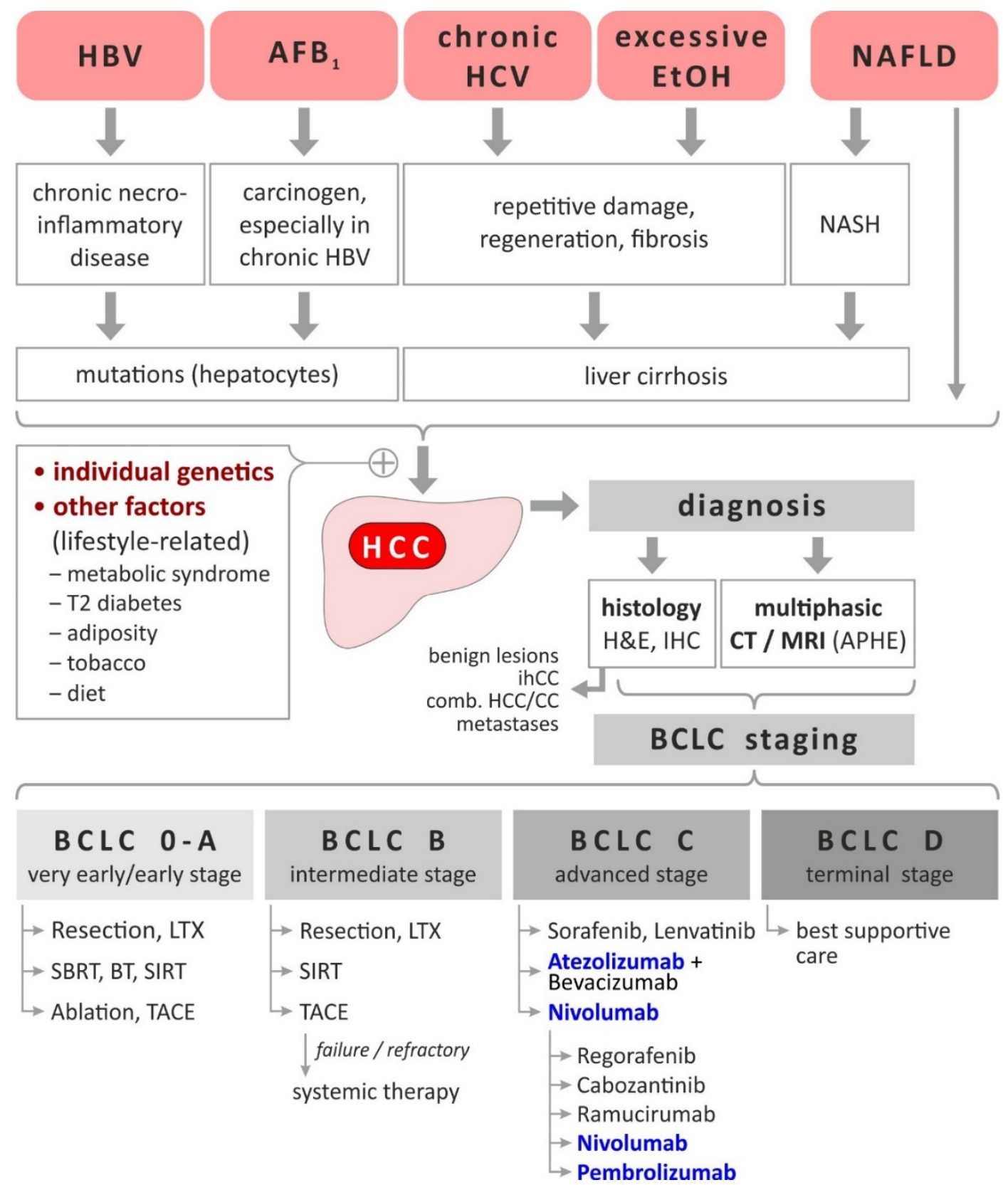

Figure 1. HCC-Etiology, risk factors, diagnosis and staging-dependent current treatment. Based on [3,5,8,15]. Immunomodulatory treatments are highlighted bold and blue. Abbreviations: $\mathrm{AFB}_{1}$, aflatoxin $\mathrm{B}_{1}$; $\mathrm{APHE}$, arterial phase hyperenhancement; BCLC, Barcelona Clinic Liver Cancer; BT, brachytherapy; CT, computed tomography; EtOH, ethanol; H(B/C)V, hepatitis B/C virus; H \& E, hematoxylin \& eosin; HCC, hepatocellular carcinoma; (ih)CC), (intrahepatic) cholangiocarcinoma; IHC, immunohistochemistry; LTX, liver transplantation; MRI, magnetic resonance imaging; NAFLD, nonalcoholic fatty liver disease; NASH, nonalcoholic steatohepatitis; SBRT, stereotactic body radiotherapy; SIRT, selective internal radiotherapy; T2 diabetes, type 2 diabetes; TACE, transarterial chemoembolisation.

In the subsequent sections, this review summarizes the use of immunomodulatory agents for treatment of HCC-in particular, immune checkpoint inhibitors (ICIs). This subset of membrane-bound molecules fine-tune the immune response by preventing continuous $\mathrm{T}$ cell effector function after prior stimulation of antigen-specific $\mathrm{T}$ cells thus serving an immunosuppressive function to prevent uncontrolled $T$ cell responses [16]. In the context of human cancer therapy, the currently most studied ICIs are PD1 (programmed cell death protein 1), CTLA-4 (cytotoxic T lymphocyte protein 4), LAG-3 (lymphocyte activation 
gene 3 protein), and, TIM-3 (T cell immunoglobulin and mucin-domain containing)-for an overview including the respective ligands, see also Figure 2.
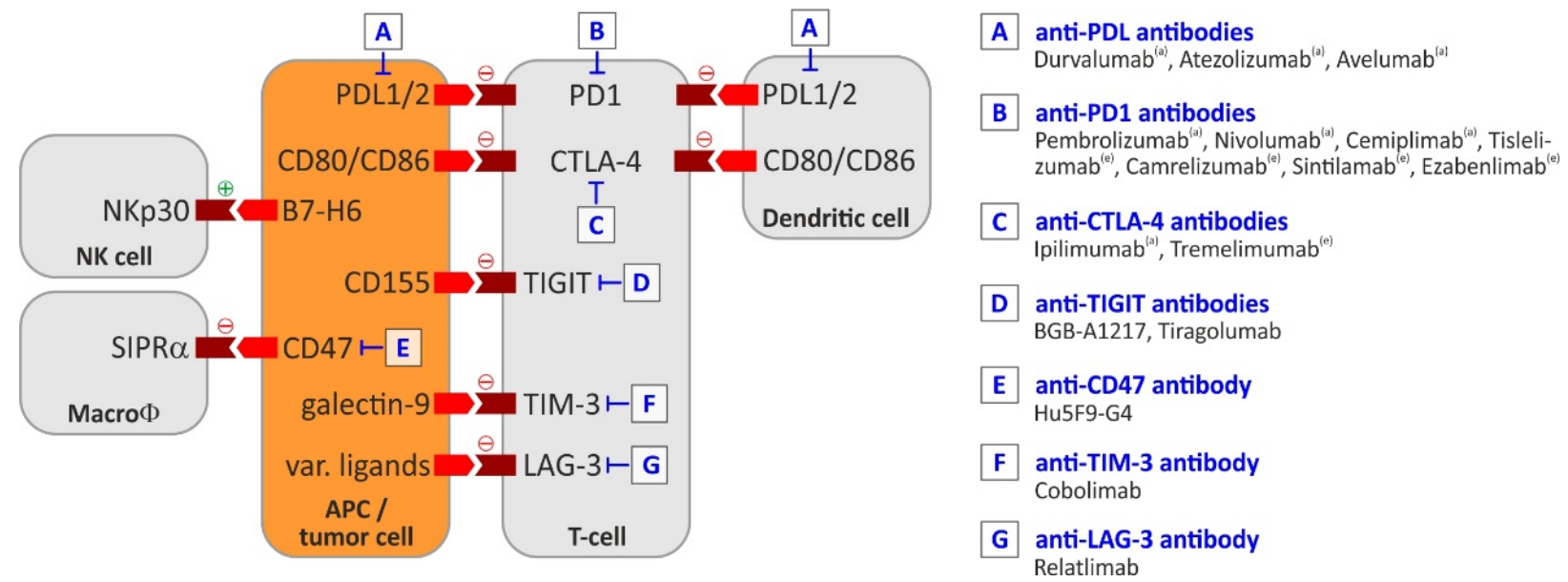

Figure 2. The most important immune checkpoints. Based on [16-22]. Abbreviations: APC, antigen-presenting cell; CTLA-4, cytotoxic T lymphocyte protein 4; LAG-3, lymphocyte activation gene 3 protein; PD1, programmed cell death protein 1; PDL1/2, programmed cell death protein ligand 1/2; TIGIT, T cell immunoreceptor with immunoglobulin and ITIM domains; TIM-3, T cell immunoglobulin and mucin-domain containing.

As discussed recently [23,24], HCC represents a tumor which could be especially attractive for using immunomodulatory drugs because: (i) the liver itself covers important immune functions by filtering infectious agents from the blood flow or from the gastrointestinal system and, therefore, is permanently exposed to various antigens requiring a certain immune tolerability, and, (ii) HCC arises from typical inflammatory conditions (cirrhosis, hepatitis, see above) and can thus be considered an inflammation-related cancer with potential immunogenicity. The currently poor prognosis of HCC patients at advanced stages requires continuous efforts in identifying specific and more effective anti-HCC approaches. Here, the status of immunomodulatory drugs for treatment of HCC is discussed with special emphasis on currently available clinical data, possible combinations with established systemic therapies and local-ablative techniques as well as an outlook on possible future strategies.

\section{Immunological Based Therapies in HCC}

\subsection{Established/Approved Immunotherapeutics in HCC}

\subsubsection{Established/Approved Immunotherapeutics in HCC}

Treatment options in advanced HCC (BCLC C) have evolved rapidly over the last 3 years. After the implementation of the tyrosine kinase inhibitor (TKI) sorafenib in 2005 for advanced HCC [25], it took more than 10 years until levantinib was able to show comparable efficacy and was approved for the treatment of HCC [26]. The established first-line treatment options opened the possibility for second-line studies. After having progressed during sorafenib, treatment with regorafenib and cabozantinib showed efficacy in phase-III studies [27,28] and extended the use of TKI in HCC. Further treatment options in second-line consist of the use of ramucirumab (IgG1 targeting the extracellular domain of VEGF receptor 2), the first monoclonal antibody that has been approved for the use in HCC treatment [29]. The effect of ramucirumab was limited to those patients with elevated AFP levels. With an AFP level of higher than $400 \mathrm{ng} / \mathrm{mL}$, the first predictive biomarker was introduced to the treatment of HCC. All those treatment options were in the pre-immune checkpoint era and consisted of TKIs or monoclonal antibodies.

Early phase II studies investigating single agent use of immune-checkpoint inhibitors showed encouraging results and let to the premature approval of pembrolizumab (target: 
PD-1). The results of the respective phase III studies (KEYNOTE-240 and CheckMate 459) were disappointing. KEYNOTE-240 evaluated the efficacy of pembrolizumab in second line compared to placebo. The primary endpoints, OS and PFS, were improved by the use of pembrolizumab but did not meet their pre-specified statistical significance [30]. The use of nivolumab (target: PD-1) compared to sorafenib in the first-line setting was investigated in the CheckMate-459 study. The primary endpoint OS was not significantly improved [31] but both studies showed a favorable safety profile proofing the feasibility and low toxicity of immune checkpoint inhibitors in advanced HCC (aHCC).

The combination of immunecheckpoint inhibitors with anti-angiogenic substances or TKI's revealed surprisingly positive results. Within the ImBrave-150 study, atezolizumab (target: PD-L1) was combined with bevacizumab (target: VEGF) and compared against sorafenib in first-line treatment of aHCC [32]. With Hazard ratios of 0.59 and 0.58 respectively, both, PFS and OS were statistically and clinically significantly improved. The use of atezolizumab and bevacizumab has set the new standard for first-line treatment of aHCC and recent data confirmed these preliminary data with a MPFS of 6.8 months and and ORR of $27 \%$ vs. 4.3 months and $12 \%$, respectively, for sorafenib [33]. Table 1 gives and overview of the approved treatment options in HCC.

Table 1. Approved substances in the treatment of aHCC.

\begin{tabular}{|c|c|c|c|}
\hline Substance & $\begin{array}{l}\text { Year of } \\
\text { Approval }\end{array}$ & Study & $\begin{array}{l}\text { Comments } \\
\text { and Primary Endpoint }\end{array}$ \\
\hline \multicolumn{4}{|l|}{ First-Line Options } \\
\hline Sorafenib & 2005 & SHARP & $\begin{array}{l}\text { OS vs. placebo: } 10.7 \text { mo vs. } \\
7.9 \text { mo; (HR } 0.69 \text { ) }\end{array}$ \\
\hline Levantinib & 2018 & REFLECT & $\begin{array}{c}\text { OS: } 13.6 \text { mo vs. } 12.3 \text { mo } \\
\text { (HR } 0.92)\end{array}$ \\
\hline Atezolizumab + Bevacizumab & 2020 & ImBrave-150 & $\begin{array}{c}\text { OS vs. sorafenib } \\
\text { OS: not reached vs. } 13.2 \text { mo } \\
\text { (HR 0.58) }\end{array}$ \\
\hline \multicolumn{4}{|l|}{ Second-Line Options } \\
\hline Regorafenib & 2017 & RESORCE & $\begin{array}{l}\text { After sorafenib first-line } \\
\text { vs. BSC } \\
\text { OS: } 10.6 \text { mo vs. } 7.8 \mathrm{mo} \\
\text { (HR 0.63) }\end{array}$ \\
\hline Cabozantinib & 2019 & CELESTIAL & $\begin{array}{l}\text { After sorafenib first-line vs. } \\
\text { BSC } \\
\text { OS: } 10.2 \text { mo vs. } 8.0 \text { mo } \\
\text { (HR 0.76) }\end{array}$ \\
\hline Ramucirumab & 2019 & REACH-2 & $\begin{array}{l}\text { After sorafenib first-line } \\
\text { vs. BSC in patients with AFP } \\
>400 \mathrm{ng} / \mathrm{mL} \\
\text { OS: } 8.5 \text { mo vs. } 7.3 \text { mo } \\
\text { (HR 0.71) }\end{array}$ \\
\hline
\end{tabular}

AFP: alpha fetoprotein; aHCC: advanced hepatocellular carcinoma; BSC: best supportive care; HR: hazard ratio; OS: overall survival; mo: months.

Ongoing studies evaluate the efficacy of double immunecheckpoint inhibition using PD-L1 inhibition and CTLA4 inhibition. The NCT02519348 study has shown efficacy and tolerability for the combination of tremelimumab (target: CTLA-4) and durvalumab (target: PD-L1) [34].

\subsubsection{Therapies with Immunologic Component}

Locoregional therapy strategies (including transarterial embolization (TAE), transarterial chemoembolization (TACE), transarterial radioembolization (TARE), and ablative therapies like radiofrequency or (RFA) and microwave ablation (MWA)) are now routinely 
used in the adjuvant and neoadjuvant treatment of hepatocellular carcinoma [35]. Besides local therapeutic effects on tumor shrinkage, tumor necrosis and local reparative processes in the liver, systemic effects are already recognized, although the clinical relevance of this inflammatory response is not fully understood until now. Nevertheless, the increasing immunotherapy options for HCC raise the question, how combination treatment strategies could improve local ablative techniques and, vice versa, how those invasive procedures could impact on immunotherapy approaches. Therefore, the following chapter will summarize the known findings in animal studies and in patients as already recently reviewed in detail [36].

The first ablative experiments were performed with a locoregional VX-2 rabbit model, which served to establish the ablative techniques for clinical beginners and to investigate experimentally the "therapeutic" effects [37]. The application of VX2 was criticized due to following reasons: (i) the used VX2 tumor, an anaplastic squamous cell carcinoma induced by papilloma virus is not and does not reflect the typical HCC morphological and molecular phenotype; (ii) genetically heterogeneity between VX2 tumor specimen and animal recipient raise the question of being an allograft, rather than an autograft-model overall [36]. Therefore, animal models with spontaneous HCC development by treatment with the toxin diethylnitrosamine or by woodchuck hepatitis virus infection should reflect more the real immunological in situ situation than the "classical" VX2 tumor model [38]. A meta-analysis revealed that carcinogen induced tumor models showed the best correlation with clinical responses [39].

How does necrosis induce unspecific or even specific inflammatory response in these experimental in vitro and in vivo settings? Interestingly, while apoptosis, but not necrosis, was linked to the inflammatory reaction in vitro [40], the in vivo situation of the necrosisinflammation-axis is quite complex, since immunogenic and non-immunogenic cell death is involved in this process [41]. Our own experiments with RFA in the VX2 model revealed that the local tumor control was paralleled by a local and systemic inflammatory reaction of activated T-cells [42]. The presented tumor antigens, released by tumor ablative techniques, could induce a localized immune response and activate a heterogeneous systematic immune response via antigen presenting cells like dendritic cells [43,44]. Additionally, combination of tumor ablation with checkpoint inhibitors like anti-CTLA4 could enhance anti-tumor immunity in vivo, too $[45,46]$. Consequently, the additional application of CpGs could improve this effect [47].

Effects on the immune response were clinically investigated in different patients' cohorts with HCC treated with different locoregional therapies like MWA, RFA, TACE or radioembolization with Y90 alone or in combination (as summarized in Figure 3). One major concern is linked to the fact, that the immune response is mostly analyzed in peripheral blood and not in the primary targeted liver tissue, limiting essentially the impact of such investigations. Furthermore, the immune outcome parameters are not strictly the same ranging from immune cells and cytokines to tumor-associated antigens. Lastly, transfer experiments of such "stimulated" immune cells and their cytokine and tumor-associated antigen counterparts are missing as proof of principle. Nevertheless, major findings of immune responses after locoregional treatment strategies of HCC are described in brief:

(1) MWA induces T-cell activation and IL-12 release [48,49].

(2) The RFA associated T cell response is specific to thermally ablated HCC extracts [50] and is also specific for tumor-associated antigens [51]. Furthermore, patients receiving RFA showed reduced frequency of myeloid-derived suppressor cells, which inversely correlates with tumor progression or relapse [52]. Treatment with RFA or TACE induces glypican-3 peptide specific cytotoxic T-lymphocytes compared to surgical resection which is a very interesting target for typical Glypican-3 overexpressing HCCs [53].

(3) Treatment with TACE leads to a change in inflammatory cytokine towards a Th2 profile [54] and an enhancement of CD4+CD25+ regulatory T cells [55]. 
(4) Radioembolization with Y90 leads to an increase in TNFA on CD4 and CD8 cells paralleled by an enhancement of antigen-presenting cells [56].

locoregional
therapies sample type immune-specific result/outcome

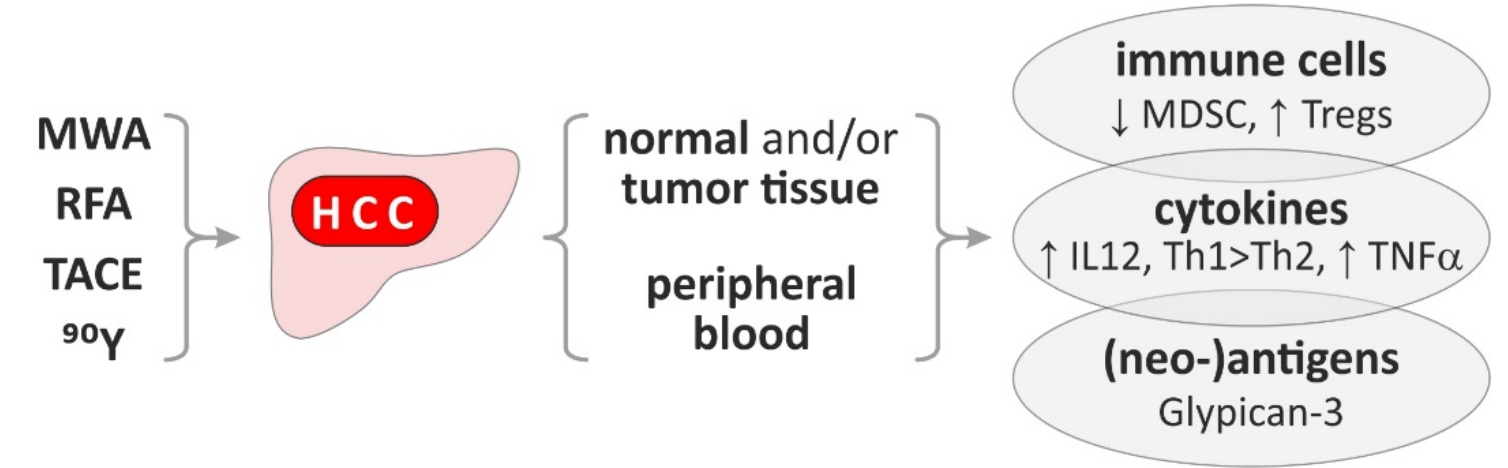

Figure 3. Overview of known immune effects of locoregional therapies for HCC. The arrows indicate the up- or downregulation of the observed immune effects. Based on [48-56]. Abbreviations: ${ }^{90} \mathrm{Y}, \mathrm{XYZ}$; HCC, hepatocellular carcinoma; IL, interleukin; MDSC, myeloid-derived suppressor cells; MWA, microwave ablation; RFA, radiofrequency ablation; TACE, transarterial chemoembolisation; TNF, tumor necrosis factor; Treg, regulatory T cell.

Finally, ongoing clinical trials investigated the combination of immune checkpoint inhibitors and locoregional ablative therapeutic strategies: Greten et al. initiated a clinical trial with 39 HCC patients who progressed after sorafinib therapy with a locoregional therapy after tremelimumab treatment [36] and confirmed the median overall survival of 10.9 months with a one complete and seven partial response as seen in an earlier study [57]. The additional molecular analysis of the peripheral blood of these treated patients revealed an increase of the PD1 expression on CD4+ and CD8+ T-cells.

Searching at the clinical trial registry (https: / / www.clinicaltrials.gov/ lastly accessed on 15 February 2021) with the term "HCC" for the disease input box and "immunotherapy and locoregional therapy" for other terms input box (last updated 3 February 2021) the database query indicates only six recruiting clinical trials (see Table 2).

Due to the low number of studies and the heterogeneous study designs (different locoregional interventions, different combination partners), a more structured analysis of these strategies is needed in the future.

Taken together, there is evidence that tumor destruction via apoptosis and necrosis could induce a local immune response via activation of $\mathrm{T}$ cells and dendritic cells and via suppression of regulatory $\mathrm{T}$ cells and of myeloid-derived suppressor cells. This is associated with a change of inflammatory cytokines, whereby specific agonist like CpGs or antagonists like anti-CTL4 could enhance the anti-tumor immunity.

Under these circumstances, the clinical efficacy of immune modulation via checkpoint inhibitors is essentially influenced by the baseline immune response and by triggering pre-existing immunity, leading to the concept of "hot" and "cold" tumors on the basis of level and spatial distribution of CD3+ and CD8+ T cell infiltration into the tumor [58,59]. The already mentioned response rate of e.g., atezolizumab and bevacizumab in HCC is mostly comparable to a rate of "hot" HCC of about 20-30\% [60,61]. Although this is in line with results found in many other cancers, it is surprising for HCC since the liver plays a central role in human immune regulation via the complex interaction of sinusoidal endothelial cells and resident macrophages (Kupffer cells) with NK cells and different CD4+/CD8+ T cell subsets and many HCCs develop on the basis of an underlying chronic inflammatory process [62,63]. As recently discussed elsewhere, the main issue to overcome the limitations of immunotherapy (alone or in combination) is to include the specific immunogenicity of tumor cells in relation to immune escape mechanisms in HCC [60]. 
Possible new treatment strategies for "cold" HCC could be based on intensive immune priming (e.g., vaccines, adoptive cell therapy or oncolytic approaches) and modulation (e.g., classical radiotherapy, chemotherapy and targeted therapy) to essentially enhance response to checkpoint inhibitors [58] as also addressed in the following sections.

Table 2. Ongoing studies investigating the combination of locoregional therapies and immunotherapy.

\begin{tabular}{|c|c|c|c|c|c|}
\hline Start Date & NCT & Title & $\begin{array}{c}\text { Local } \\
\text { Interventions }\end{array}$ & $\begin{array}{l}\text { Immuno- } \\
\text { Modulator }\end{array}$ & Phase \\
\hline $01 / 2020$ & NCT04220944 & $\begin{array}{c}\text { Combined locoregional treatment } \\
\text { with immunotherapy for } \\
\text { unresectable HCC. }\end{array}$ & MWA/TACE & Sintilimab & 1 \\
\hline $05 / 2019$ & NCT03753659 & $\begin{array}{l}\text { IMMULAB-immunotherapy with } \\
\text { pembrolizumab in combination } \\
\text { with local ablation in } \\
\text { hepatocellular carcinoma (HCC) }\end{array}$ & $\begin{array}{l}\text { RFA, MWA, } \\
\text { Brachytherapy, } \\
\text { TACE }\end{array}$ & Pembrolizumab & 2 \\
\hline $11 / 2019$ & NCT04273100 & $\begin{array}{l}\text { PD-1 monoclonal antibody, } \\
\text { lenvatinib and TACE in the } \\
\text { treatment of HCC }\end{array}$ & TACE & $\begin{array}{l}\text { PD-1 mAb and } \\
\text { lenvatinib }\end{array}$ & 2 \\
\hline $09 / 2020$ & NCT04518852 & $\begin{array}{l}\text { TACE, Sorafenib and PD-1 } \\
\text { monoclonal antibody in the } \\
\text { treatment of HCC }\end{array}$ & TACE & $\begin{array}{l}\text { sorafenib and } \\
\text { PD-1 mAb }\end{array}$ & 2 \\
\hline $05 / 2019$ & NCT03867084 & $\begin{array}{l}\text { dafety and efficacy of } \\
\text { pembrolizumab (MK-3475) versus } \\
\text { placebo as adjuvant therapy in } \\
\text { participants with hepatocellular } \\
\text { carcinoma (HCC) and complete } \\
\text { radiological response after } \\
\text { surgical resection or local ablation } \\
\text { (MK-3475-937/KEYNOTE-937) }\end{array}$ & Local ablation & Pembrolizumab & 3 \\
\hline $05 / 2019$ & NCT04268888 & $\begin{array}{l}\text { Nivolumab in combination with } \\
\text { TACE/TAE for patients with } \\
\text { intermediate stage HCC }\end{array}$ & TACE/TAE & Nivolumab & $2 / 3$ \\
\hline
\end{tabular}

HCC: hepatocellular carcinoma; MWA: microwave ablation; RFA: radiofrequency ablation; TACE: trans-arterial chemo-embolization; TAE: trans-arterial embolization.

\subsection{Future Options of HCC Linked Immunmodulation}

As shown in Figure 2, currently approved immune checkpoint inhibitors reactivate $\mathrm{T}$ cells by modulating the CTLA-4 or PD-1/PD-L1 signaling pathways. Interestingly, also other immunosuppressive molecules like TIM3 or LAG3 were found to be significantly increased in tumor-associated antigen specific HCC infiltrating CD $8^{+}$lymphocytes and may represent valuable targets for novel therapeutic approaches alone or in combination [64]. The general importance of $\mathrm{T}$ cell mediated anti-tumor effects has also been confirmed by an increasing number of CAR T approaches in HCC, usually targeting glypican 3 or AFP [65]. A recent report also demonstrated that hepatic $\mathrm{FasL}^{+} \mathrm{CD} 11 \mathrm{~b}^{+} \mathrm{F} 4 / 80^{+}$monocytederived macrophages can siphon activated $\mathrm{CD}^{+} \mathrm{T}$ cells and contribute to limited efficacy of immunotherapy [66]. In this section we will therefore expand the view also to myeloid cells like macrophages NK cells as well as the above-mentioned T cell checkpoints TIM-3, LAG-3 and TIGIT which have not yet been targeted in HCC.

\subsubsection{TIM-3}

T cell immunoglobulin and mucin domain 3 (TIM-3), alias hepatitis A virus cellular receptor 2 (HAVCR2)) is an immunosuppressive surface molecule that is expressed on T cells, dendritic cells, NK cells, macrophages and also on HCC cells [67]. It is commonly co-expressed with other immune checkpoint receptors like PD-1. Activation of TIM3 leads to immune exhaustion of $\mathrm{CD} 8^{+} \mathrm{T}$ cells and its expression on $\mathrm{CD}^{+}$regulatory $\mathrm{T}$ cells $\left(\mathrm{T}_{\mathrm{reg}}\right)$ is associated with advanced tumor stage [68]. On macrophages, TIM-3 can 
stimulate the M2 polarization and promote tumor growth by increasing IL-6 secretion [69]. Not surprisingly, TIM-3 expression has thus been correlated to poor prognosis in various human cancers, including HCC [70-72]. Four ligands binding to TIM-3 have so far been identified: Galectin-9, phosphatidylserine, high-mobility group protein B1 (HGMB1) and carcinoembryonic antigen-related cell adhesion molecule-1 (CEACAM-1) [73]. Galectin-9 is produced by numerous cells types, including $B$ and $T$ cells, macrophages, and dendritic cells but also by epithelial cells, cancer cells and fibroblasts. In HCC, opposing effects of Galectin-9 have been described that are not well understood so far: while it is able to induce apoptosis in in vitro and in in vivo HCC models [74], it contributes to the immune exhaustion in HBV-associated HCC in patients and is a predictor for poor prognosis [72]. Interestingly, high levels of Galectin-9 have also been linked to advanced stages of liver fibrosis and cirrhosis in patients, underlining the connection between chronic inflammatory liver damage, fibrosis and HCC [75].

Several inhibitors for TIM-3 signaling have been developed (Table 3) [68,73]. While several compounds investigate TIM-3 blockade in various solid tumors, only one investigator sponsored study is specifically looking into HCC. Here, the anti-TIM-3 IgG4 antibody cobolimab is used in combination with the anti-PD1 antibody dostarlimab (both manufactured by Tesaro/GSK) in adult patients with BCLC stage B or C HCC and no prior systemic therapy. The study is ongoing and no interim data have been reported so far.

Table 3. TIM-3 inhibitors in clinical development.

\begin{tabular}{|c|c|c|}
\hline Compound & Company & Status/Comment \\
\hline BMS-986258 & BMS & $\begin{array}{l}\text { Phase } 1 \text { in solid tumors in } \\
\text { combination with nivolumab }\end{array}$ \\
\hline $\begin{array}{c}\text { Cobolimab } \\
\text { (TSR-022, GSK4069889) }\end{array}$ & Tesaro/GSK & $\begin{array}{l}\text { Various Phase } 1 \text { studies ongoing } \\
\text { +PD-1 in HCC (NCT03680508) }\end{array}$ \\
\hline INCAGN02390 & Incyte & Phase 1 in solid tumors \\
\hline LY3321367 & Eli Lilly & $\begin{array}{l}\text { PD-1/TIM-3 bispecific } \\
\text { Development stopped }\end{array}$ \\
\hline RG7769 (RO7121661) & Roche & $\begin{array}{l}\text { PD-1/TIM-3 bispecific } \\
\text { Phase } 1 \text { in solid tumors }\end{array}$ \\
\hline Sabatolimab (MBG 453) & Novartis & Only in hematologic malignancies \\
\hline Sym023 & Symphogen & $\begin{array}{c}\text { Phase } 1 \text { in combination with PD-1 } \\
\text { and/or LAG-3 antibodies }\end{array}$ \\
\hline
\end{tabular}

\subsubsection{LAG-3}

The lymphocyte activation gene 3 protein (LAG-3; CD223) is another strong suppressor of $\mathrm{T}$ cell function. It is expressed on tumor infiltrating lymphocytes $\left(\mathrm{CD}^{+}\right.$and $\mathrm{CD} 8^{+} \mathrm{T}$ cells), $\mathrm{T}_{\text {reg, }}$ NKT cells. B cells, NK cells, plasmacytoid dendritic cells (pDCs) and on tumor associated macrophages (TAMs) [76]. It regulates the immune response by inhibiting the proliferation and activation of $\mathrm{T}$ cells, by inducing $\mathrm{T}_{\text {reg }}$ and by blocking $\mathrm{T}$ cell activation from antigen presenting cells (APCs) [77]. LAG-3 is commonly co-expressed with PD-1 in $\mathrm{T}$ cell exhausted cancers and contributes to resistance to immune checkpoint inhibitor therapy [78-80]. For LAG-3, too, four ligands have been identified today: major histocompatibility complex class II proteins (MHC-II) [81], liver sinusoidal endothelial cell lectin (LSECtin) [82], Galectin-3 [83] and fibrinogen-like protein 1 (FGL-1) [84]. All ligands are of relevance for HCC formation: while MHC-II is expressed on activated APCs (Kupffer cells), the other ligands can be expressed by hepatocytes or sinusoidal endothelial cells which also play a role in chronic liver damage, fibrotic remodeling, angiogenesis and tumor formation [85-89]. LAG-3 expression has therefore also been associated to poor prognosis in various human cancers including HCC [90,91].

Preclinical data indicated a strong anti-tumor efficacy of LAG-3 antagonists, esp. when combined with anti-PD-1 agents [92-95]. Thus, about 15 large-molecule antagonists against LAG-3 (either mono- or bispecific against PD-1) are currently investigated preclinically or in early clinical studies (recently reviewed by Lecocq et al. [76]). Yet, single agent 
activity if those compounds was only limited and most trials now combine anti-LAG-3 with anti-PD-1 approaches. Currently, five studies investigating such approaches in HCC are listed at clinicaltrials.gov (Table 4). So far, only the Phase 1 study for INCAGN02385 (NCT03538028) is completed and enrolled a total of 22 patients across multiple solid tumor indications, including HCC, but no data was reported so far. Specific studies for HCC are only conducted with the IgG4 anti-LAG3 antibody relatlimab (BMS-986016) in combination with nivolumab in either resectable (NCT04658147) or in immunotherapy naïve patients after failure of tyrosine kinase inhibitors (NCT04567615).

Table 4. LAG-3 inhibitors investigated in HCC.

\begin{tabular}{|c|c|c|c|c|c|}
\hline Compound & Company & Combination & $\mathbf{N}$ & Phase & NCT \\
\hline INCAGN02385 & Incyte & & $\begin{array}{l}22 \text { (advanced } \\
\text { solid tumors) }\end{array}$ & 1 & NCT03538028 \\
\hline Relatlimab & BMS & Nivolumab & 20 & 1 & NCT04658147 \\
\hline Relatlimab & BMS & Nivolumab & 250 & 2 & NCT04567615 \\
\hline SRF388 & Surface Oncology & & $\begin{array}{c}122 \text { (advanced } \\
\text { solid tumors, with } \\
n=40 \text { HCC } \\
\text { expansion arm) }\end{array}$ & 1 & NCT04374877 \\
\hline $\mathrm{XmAb}^{\circledR} 22841$ & Xencor & Pembrolizumab & $\begin{array}{c}242 \text { (advanced } \\
\text { solid tumors) }\end{array}$ & 1 & NCT03849469 \\
\hline
\end{tabular}

\subsubsection{TIGIT}

The $\mathrm{T}$ cell immunoreceptor with immunoglobulin and ITIM domains (TIGIT) is expressed on activated NK and T cells, including CD4+ and CD8+ T cells, as well as $\mathrm{T}_{\text {reg }}$ and $T$ helper cell populations under resting conditions to exert an immunosuppressive condition [96]. CD155 was identified as the main ligand, mainly expressed on DCs, macrophages, B and T cells. CD112 (Nectin-2) and CD113 (Nectin-3) bind to TIGIT with lower affinity and all three ligands can also be detected in the liver. TIGIT was found to be upregulated in patients with advanced fibrosis [97] and in chronic viral hepatitis leading to HCC [98]. In preclinical HCC models, TIGIT contributed to immunosuppressive effects and potentially resistance to PD-1 treatment $[99,100]$. In clinical samples, TIGIT expression increased with tumor dedifferentiation and with higher AFP expression [101].

Several monoclonal anti-TIGIT antibodies, usually IgG1 subtypes, are currently undergoing early clinical testing (recently reviewed by Harjunpaa and Guillerey [96]). Most compounds are tested in combination with anti-PD-1 or anti-PD-L1 antibodies but no study is specifically investigating HCC yet. Recently, tiragolumab in combination with atezolizumab received FDA breakthrough therapy designation for the first-line treatment of metastatic non-small cell lung cancer with high PD-L1 expression and no mutations in EGFR or ALK [102]. Further studies that also investigate HCC are expected. For other compounds, e.g., vibostolimab (MK-7684), etigilimab (OMP-313M32), domvanalimab (AB154), BMS-986207, ASP8374 or BGB-A1217 are currently in Phase 1 studies in various solid tumors with a focus on NSCLC.

\subsubsection{B7-H6}

The B7 receptor family (alias natural cytotoxicity triggering receptor 3 or NCR3, Ligand 1) represents co-receptors to e.g., CTLA-4 or PD-1 [103]. B7-H6 is a ligand to the activating receptor NKp30 on NK cells and thus contributes to their activation [104]. B7-H6 mediated activation of NK cells leads to cytokine release (IFN-g) and enhanced cytotoxicity. Besides immunological effects, B7-H6 does also regulate intracellular signaling pathways, esp. STAT3 signaling, which are associated with apoptosis inhibition and induction of cell proliferation and therefore has a dual role in cancer cell growth $[105,106]$.

While B7-H6 is usually not expressed in normal tissues, it is commonly found in different human cancers like small cell lung cancer [107], esophageal squamous cell carci- 
noma [108], gliomas [109], ovarian cancer [110] or HCC [106,111], where it is associated with poorer outcome. Unfortunately, no agents modulating B7-H6 signaling on tumor or NK cells are currently available [112].

\subsubsection{CD47-SIRPa}

CD47 is broadly expressed on normal cells, including erythrocytes. It belongs to the immunoglobulin superfamily and displays a "don't eat me"-signal to macrophages and other phagocytes. Binding of CD47 to its receptor signal regulatory protein a (SIRPa) on macrophages inhibits phagocytosis activation and can contribute to tumor formation $[113,114]$. CD47 is therefore overexpressed on various hematologic and solid tumors to evade the cellular immune response, including HCC where it is also associated to poorer outcome [21]. Consequently, blocking CD47-signaling inhibited growth of HCC models and restored sensitivity to chemotherapy [115].

Activation of CD47 on tumor cells can also lead to caspase-independent cell death induction, although the exact molecular mechanisms are still not completely understood [116]. Therapeutic approaches currently focus on inhibiting the CD47-SIRPa binding to activate phagocytosis of cancer cells and several small and large molecule inhibitors are undergoing clinical investigations. Small molecule inhibitors are currently in preclinical stage only and have been recently reviewed elsewhere [117]. Table 5 gives an overview of large molecule CD47 inhibitors in early clinical trials. None of these agents is specifically investigated in HCC.

Table 5. Anti-CD47 antibodies in early clinical development.

\begin{tabular}{|c|c|c|}
\hline Compound & Company & Status/Comment \\
\hline AK117 & Akeso & Phase 1 \\
\hline ALX148 & ALX Oncology & Phase 2 combinations \\
\hline $\mathrm{AO}-176$ & Arch Oncology & $\begin{array}{c}\text { Phase } 1 \text {, combination with } \\
\text { paclitaxel }\end{array}$ \\
\hline $\begin{array}{l}\text { CC-90002 } \\
(\text { INBRX103) }\end{array}$ & Celgene & Phase 1 \\
\hline HX009 & Hanxbio & Phase 1 \\
\hline IBI188 & Innovent Biologics & Phase 1 \\
\hline IBI322 & Innovent Biologics & Phase 1 \\
\hline IMC-002 & ImmuneOncia Therapeutics & Phase 1 \\
\hline $\begin{array}{l}\text { Magrolimab } \\
\text { (Hu5F9-G4) }\end{array}$ & Gilead & $\begin{array}{c}\text { Phase } 3 \text {, received } \\
\text { breakthrough therapy } \\
\text { designation for MDS, Phase } \\
\text { 1b combination studies in } \\
\text { solid tumors }\end{array}$ \\
\hline SGN-CD47M & Seattle Genetics & Terminated \\
\hline SRF231 & Surface Oncology & Phase 1 completed \\
\hline ZL-1201 & ZaiLab & Phase 1 \\
\hline
\end{tabular}

Recently, a Phase 1 study with the bi-functional SIRPa-Fc-CD40L antibody SL-172154 was initiated (NCT04406623). This agent targets CD47 on tumors and CD40 on antigen presenting cells to enhance antigen presentation to $\mathrm{T}$ cells and to induce tumor cell killing.

\subsubsection{Additional in-Silico-Analysis of HCC Linked Immunmodulation via TUMOR} Immune Estimation Resource (TIMER)

We performed an additional in silico analysis of TIM3, LAG3, TIGIT, B7-H6 and CD47-SIRPa to explore the correlation of these markers of immunomodulation in situ by using the online platform TIMER, which is based on 10,897 samples across 32 cancer types from The Cancer Genome Atlas (TCGA) [118]. This included 363 primary HCC samples with mainly male patient population $(66 \%)$ of caucasian ethnicity $(60 \%)$ showing mostly a moderate differentiation (50\%) and a relative homogenous UICC-stage distribution (Stage I 39\%, II, 22\%, III 31\% and IV 3\%. missing 6\%) as already published [61]. 
We focused on the gene module of TIMER to investigate the correlation with the tumor purity and the six tumor infiltration subsets of B cells, CD8+ T cells, CD4+ T cells, macrophages, neutrophils and dendritic cells in HCC as presented in Figure 4.

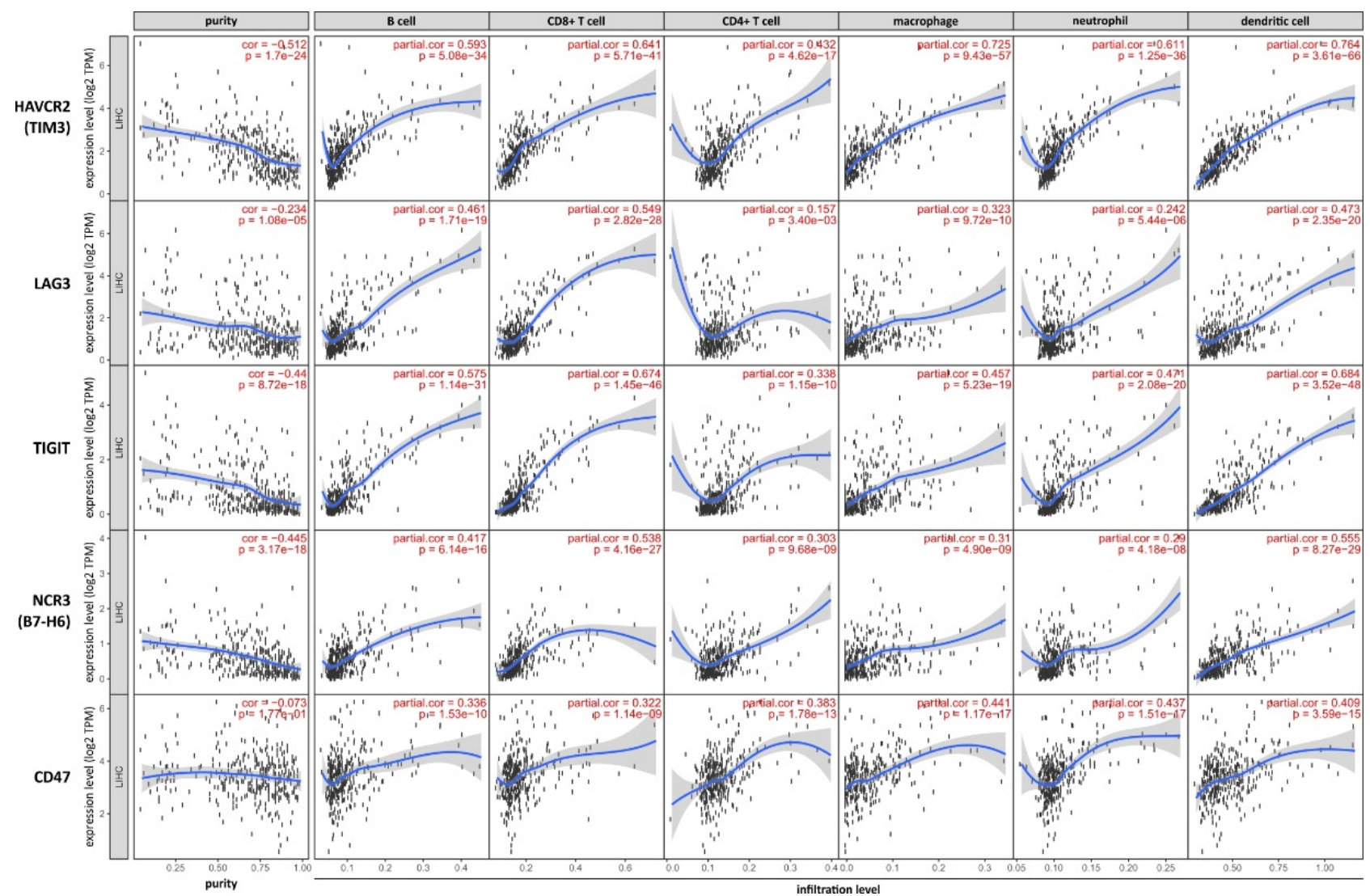

Figure 4. In silico analysis using TIMER with the gene module for markers of immune modulation TIM3, LAG3, TIGIT, B7-H6 and CD47-SIRPa in HCC.

Overall, all markers of immunomodulation showed a negative correlation with the tumor purity indicating that all markers are more found at the tumor border than in the tumor center. Furthermore, all markers of immunomodulation were positively associated with $\mathrm{B}$ cells, CD8+ T cells, CD4+ T cells, macrophages, neutrophils and dendritic cells in HCC, with a partial correlation factor reaching up to $0.725 / 0.764$ for TIM3 and macrophages/dendritic cell. This indicates a very strong association with tumor infiltrating immune subsets in HCC, especially with antigen presenting cells.

This in silico analysis revealed two major patterns of correlation in dependency of infiltration density of tumor infiltrating immune cells: immunomodulators like TIM3 and TIGIT showed parallel increasing expression, while the immunomodulators LAG3, B7-H6 and CD47 displayed a heterogeneous expression pattern compared to the density of tumor cells. Taken together, the in silico analysis indicates that the density of tumor infiltrating immune cells like B cells, CD8+ T cells, CD4+ T cells, macrophages, neutrophils and dendritic cells is mostly paralled by the expression of selective markers of immunmodulation. Therefore, the tumor compartments as well as the specific subsets of immune cells, too, must be integrated in the evaluation as biomarkers for consecutive immune checkpoint therapy in HCC.

\section{Conclusions}

In summary, the growing understanding and knowledge of carcinogenesis, diagnosis and possible treatment strategies for patients with HCC did so far not essentially improve the outcome of patients suffering from HCC, with 5-year survival rates of only about 
$8 \%$ and high tumor recurrence rates after resection [119]. Consequently, investigating alternative therapeutic strategies for HCC is an urgent necessity [65].

The development of immune checkpoint inhibitors like anti-CTLA4 (ipilimumab, tremelimumab) or anti-PD-1/PD-L1 (nivolumab, pembrolizumab, tislelizumab, camrelizumab, atezolizumab, durvalumab, avelumab) antibodies has dramatically revolutionized the field of clinical oncology leading to impressing treatment responses in different human cancer types.

Results from recent clinical trials combining a checkpoint inhibitor with either multityrosine kinase inhibitors or angiogenesis inhibitors confirmed that HCC is an inflamed ("hot") tumor. The combination of atezolizumab and bevacizumab received approval for 1 st line therapy. Still, the objective response rates of these combinations barely exceed 25 to $30 \%$, indicate that further therapy optimization is needed.

Basic scientific investigations of HCC in vitro and in vivo, especially after locoregional treatment, created evidence that therapeutic induction of apoptosis and/or necrosis leads to significant changes of the immune cell repertoire and of immune modulating cytokines in the liver and systemically in the whole human body/system. Consequently, the idea was born to combine immune checkpoint inhibitors and locoregional treatments of HCC to potentiate the local and systemic immune response. The first results of such clinical trials gave encouraging signs on clinical endpoints like overall survival and response rate. Nevertheless, this approach of immunotherapy in combination with locoregional therapeutic approaches raised many "best" questions on the treatment modality, timing and biomarkers which must be solved in the future: What treatment modality (locoregional treatment and delivery mode of immunotherapy) is the best choice for maximal immune triggering? Which and what timing of combination is the best for deep and long-time tumor response of the HCC? Which biomarker is the best to indicate the most suitable checkpoint inhibitor?

Taken all together, recent developments of immunomodulatory treatment strategies alone or in combination will essentially change our therapeutic options for the HCC in the future.

Author Contributions: Conceptualization, M.O. and D.N.; writing-review and editing, M.O., C.M., T.K., S.S. and D.N.; visualization, C.M. and T.K. All authors have read and agreed to the published version of the manuscript.

Funding: This research received no external funding.

Institutional Review Board Statement: Not applicable.

Informed Consent Statement: Not applicable.

Data Availability Statement: No new data were created or analyzed in this study. Data sharing is not applicable to this article.

Conflicts of Interest: M.O. is an employee of Boehringer Ingelheim Pharma GmbH \& Co, Germany. Boehringer Ingelheim had no role in the design of the study; in the collection, analyses, or interpretation of data; in the writing of the manuscript, or in the decision to publish the results. The other authors declare no conflict of interest related to this publication.

\section{References}

1. Bray, F.; Ferlay, J.; Soerjomataram, I.; Siegel, R.L.; Torre, L.A.; Jemal, A. Global cancer statistics 2018: GLOBOCAN estimates of incidence and mortality worldwide for 36 cancers in 185 countries. CA Cancer J. Clin. 2018, 68, 394-424. [CrossRef]

2. Ferlay, J.; Ervik, M.; Lam, F.; Colombet, M.; Mery, L.; Piñeros, M.; Znaor, A.; Soerjomataram, I.; Bray, F. Global cancer Observatory: Cancer Today; International Agency for Research on Cancer: Lyon, France; Available online: https://gco.iarc.fr/today (accessed on 22 March 2021).

3. McGlynn, K.A.; Petrick, J.L.; El-Serag, H.B. Epidemiology of hepatocellular carcinoma. Hepatology 2020. [CrossRef]

4. Petrick, J.L.; Florio, A.A.; Znaor, A.; Ruggieri, D.; Laversanne, M.; Alvarez, C.S.; Ferlay, J.; Valery, P.C.; Bray, F.; McGlynn, K.A. International trends in hepatocellular carcinoma incidence, 1978-2012. Int. J. Cancer 2020, 147, 317-330. [CrossRef] 
5. Vogel, A.; Cervantes, A.; Chau, I.; Daniele, B.; Llovet, J.M.; Meyer, T.; Nault, J.C.; Neumann, U.; Ricke, J.; Sangro, B.; et al. Hepatocellular carcinoma: ESMO clinical practice guidelines for diagnosis, treatment and follow-up. Ann. Oncol. 2018, 29 , iv238-iv255. [CrossRef]

6. Chiang, C.J.; Yang, Y.W.; You, S.L.; Lai, M.S.; Chen, C.J. Thirty-year outcomes of the national hepatitis B immunization program in Taiwan. JAMA 2013, 310, 974-976. [CrossRef]

7. Ioannou, G.N.; Green, P.K.; Berry, K. HCV eradication induced by direct-acting antiviral agents reduces the risk of hepatocellular carcinoma. J. Hepatol. 2017. [CrossRef]

8. Ahn, J.C.; Teng, P.C.; Chen, P.J.; Posadas, E.; Tseng, H.R.; Lu, S.C.; Yang, J.D. Detection of circulating tumor cells and their implications as a novel biomarker for diagnosis, prognostication, and therapeutic monitoring in hepatocellular carcinoma. Hepatology 2020. [CrossRef]

9. Kisiel, J.B.; Dukek, B.A.; VSR Kanipakam, R.; Ghoz, H.M.; Yab, T.C.; Berger, C.K.; Taylor, W.R.; Foote, P.H.; Giama, N.H.; Onyirioha, K.; et al. Hepatocellular carcinoma detection by plasma methylated DNA: Discovery, phase I pilot, and phase II clinical validation. Hepatology 2019, 69, 1180-1192. [CrossRef]

10. Mezzalira, S.; De Mattia, E.; Guardascione, M.; Dalle Fratte, C.; Cecchin, E.; Toffoli, G. Circulating-free DNA analysis in hepatocellular carcinoma: A promising strategy to improve patients' management and therapy outcomes. Int. J. Mol. Sci. 2019, 20, 5498. [CrossRef]

11. Johnson, P.J.; Pirrie, S.J.; Cox, T.F.; Berhane, S.; Teng, M.; Palmer, D.; Morse, J.; Hull, D.; Patman, G.; Kagebayashi, C.; et al. The detection of hepatocellular carcinoma using a prospectively developed and validated model based on serological biomarkers. Cancer Epidemiol. Biomarkers Prev. 2014, 23, 144-153. [CrossRef]

12. Best, J.; Bechmann, L.P.; Sowa, J.P.; Sydor, S.; Dechene, A.; Pflanz, K.; Bedreli, S.; Schotten, C.; Geier, A.; Berg, T.; et al. GALAD score detects early hepatocellular carcinoma in an international cohort of patients with nonalcoholic steatohepatitis. Clin. Gastroenterol. Hepatol. 2020, 18, 728-735.e4. [CrossRef]

13. Lee, Y.J.; Lee, J.M.; Lee, J.S.; Lee, H.Y.; Park, B.H.; Kim, Y.H.; Han, J.K.; Choi, B.I. Hepatocellular carcinoma: Diagnostic performance of multidetector CT and MR imaging-a systematic review and meta-analysis. Radiology 2015, 275, 97-109. [CrossRef] [PubMed]

14. Forner, A.; Reig, M.; Bruix, J. Hepatocellular carcinoma. Lancet 2018, 391, 1301-1314. [CrossRef]

15. Casak, S.J.; Donoghue, M.; Fashoyin-Aje, L.; Jiang, X.; Rodriguez, L.; Shen, Y.L.; Xu, Y.; Jiang, X.; Liu, J.; Zhao, H.; et al. FDA approval summary: Atezolizumab plus bevacizumab for the treatment of patients with advanced unresectable or metastatic hepatocellular carcinoma. Clin. Cancer Res. 2020. [CrossRef]

16. Greten, T.F.; Sangro, B. Targets for immunotherapy of liver cancer. J. Hepatol. 2017. [CrossRef]

17. Marin-Acevedo, J.A.; Dholaria, B.; Soyano, A.E.; Knutson, K.L.; Chumsri, S.; Lou, Y. Next generation of immune checkpoint therapy in cancer: New developments and challenges. J. Hematol. Oncol. 2018, 11, 39. [CrossRef]

18. Ghavimi, S.; Apfel, T.; Azimi, H.; Persaud, A.; Pyrsopoulos, N.T. Management and treatment of hepatocellular carcinoma with immunotherapy: A review of current and future options. J. Clin. Transl. Hepatol. 2020, 8, 168-176. [CrossRef]

19. Zheng, Q.; Xu, J.; Gu, X.; Wu, F.; Deng, J.; Cai, X.; Wang, G.; Li, G.; Chen, Z. Immune checkpoint targeting TIGIT in hepatocellular carcinoma. Am. J. Transl. Res. 2020, 12, 3212-3224.

20. Lee, H.W.; Cho, K.J.; Park, J.Y. Current status and future direction of immunotherapy in hepatocellular carcinoma: What do the data suggest? Immune Netw. 2020, 20, e11. [CrossRef]

21. Kim, H.; Bang, S.; Jee, S.; Paik, S.S.; Jang, K. Clinicopathological significance of CD47 expression in hepatocellular carcinoma. J. Clin. Pathol. 2021, 74, 111-115. [CrossRef]

22. Qiu, H.; Gao, S.; Sun, Z.; Wang, J. Dual role of B7-H6 as a novel prognostic marker in hepatocellular carcinoma. APMIS 2021, 129, 105-117. [CrossRef]

23. Federico, P.; Petrillo, A.; Giordano, P.; Bosso, D.; Fabbrocini, A.; Ottaviano, M.; Rosanova, M.; Silvestri, A.; Tufo, A.; Cozzolino, A.; et al. Immune checkpoint inhibitors in hepatocellular carcinoma: Current status and novel perspectives. Cancers 2020, 12, 3025. [CrossRef]

24. Ruf, B.; Heinrich, B.; Greten, T.F. Immunobiology and immunotherapy of HCC: Spotlight on innate and innate-like immune cells. Cell. Mol. Immunol. 2020. [CrossRef]

25. Llovet, J.M.; Ricci, S.; Mazzaferro, V.; Hilgard, P.; Gane, E.; Blanc, J.F.; de Oliveira, A.C.; Santoro, A.; Raoul, J.L.; Forner, A.; et al. Sorafenib in advanced hepatocellular carcinoma. N. Engl. J. Med. 2008, 359, 378-390. [CrossRef]

26. Kudo, M.; Finn, R.S.; Qin, S.; Han, K.H.; Ikeda, K.; Piscaglia, F.; Baron, A.; Park, J.W.; Han, G.; Jassem, J.; et al. Lenvatinib versus sorafenib in first-line treatment of patients with unresectable hepatocellular carcinoma: A randomised phase 3 non-inferiority trial. Lancet 2018, 391, 1163-1173. [CrossRef]

27. Bruix, J.; Qin, S.; Merle, P.; Granito, A.; Huang, Y.H.; Bodoky, G.; Pracht, M.; Yokosuka, O.; Rosmorduc, O.; Breder, V.; et al. Regorafenib for patients with hepatocellular carcinoma who progressed on sorafenib treatment (RESORCE): A randomised, double-blind, placebo-controlled, phase 3 trial. Lancet 2017, 389, 56-66. [CrossRef]

28. Abou-Alfa, G.K.; Borgman-Hagey, A.E.; Kelley, R.K. Cabozantinib in hepatocellular carcinoma. N. Engl. J. Med. 2018, 379, 1384-1385. [CrossRef]

29. Zhu, A.X.; Finn, R.S.; Galle, P.R.; Llovet, J.M.; Kudo, M. Ramucirumab in advanced hepatocellular carcinoma in REACH-2: The true value of alpha-fetoprotein. Lancet Oncol. 2019, 20, e191. [CrossRef] 
30. Finn, R.S.; Ryoo, B.Y.; Merle, P.; Kudo, M.; Bouattour, M.; Lim, H.Y.; Breder, V.; Edeline, J.; Chao, Y.; Ogasawara, S.; et al. Pembrolizumab as second-line therapy in patients with advanced hepatocellular carcinoma in KEYNOTE-240: A randomized, double-blind, phase III trial. J. Clin. Oncol. 2020, 38, 193-202. [CrossRef]

31. Yau, T.; Park, J.W.; Finn, R.S.; Cheng, A.L.; Mathurin, P.; Edeline, J.; Kudo, M.; Han, K.-H.; Harding, J.J.; Merle, P.; et al. CheckMate 459: A randomized, multi-center phase III study of nivolumab (NIVO) vs sorafenib (SOR) as first-line (1L) treatment in patients (pts) with advanced hepatocellular carcinoma (aHCC). Ann. Oncol. 2019, 30, V874-V875. [CrossRef]

32. Finn, R.S.; Qin, S.; Ikeda, M.; Galle, P.R.; Ducreux, M.; Kim, T.Y.; Kudo, M.; Breder, V.; Merle, P.; Kaseb, A.O.; et al. Atezolizumab plus bevacizumab in unresectable hepatocellular carcinoma. N. Engl. J. Med. 2020, 382, 1894-1905. [CrossRef]

33. Finn, R.S.; Qin, S.; Ikeda, M.; Galle, P.R.; Ducreux, M.; Kim, T.-Y.; Lim, H.Y.; Kudo, M.; Breder, V.V.; Merle, P.; et al. IMbrave150: Updated overall survival (OS) data from a global, randomized, open-label phase III study of atezolizumab (atezo) + bevacizumab (bev) versus sorafenib (sor) in patients (pts) with unresectable hepatocellular carcinoma (HCC). J. Clin. Oncol. 2021, $39,267$. [CrossRef]

34. Kelley, R.K.; Kudo, M.; Harris, W.; Ikeda, M.; Okusaka, T.; Kang, Y.; Qin, S.; Tai, D.; Lim, H.; Yau, T.; et al. The novel regimen of tremelimumab in combination with durvalumab provides a favorable safety profile and clinical activity for patients with advanced hepatocellular carcinoma. Ann. Oncol. 2020, 31, 233-234. [CrossRef]

35. Makary, M.S.; Khandpur, U.; Cloyd, J.M.; Mumtaz, K.; Dowell, J.D. Locoregional therapy approaches for hepatocellular carcinoma: Recent advances and management strategies. Cancers 2020, 12, 1914. [CrossRef] [PubMed]

36. Greten, T.F.; Mauda-Havakuk, M.; Heinrich, B.; Korangy, F.; Wood, B.J. Combined locoregional-immunotherapy for liver cancer. J. Hepatol. 2019, 70, 999-1007. [CrossRef]

37. Hansler, J.; Neureiter, D.; Wasserburger, M.; Janka, R.; Bernatik, T.; Schneider, T.; Muller, W.; Frieser, M.; Schaber, S.; Becker, D.; et al. Percutaneous US-guided radiofrequency ablation with perfused needle applicators: Improved survival with the VX2 tumor model in rabbits. Radiology 2004, 230, 169-174. [CrossRef]

38. Dow, M.; Pyke, R.M.; Tsui, B.Y.; Alexandrov, L.B.; Nakagawa, H.; Taniguchi, K.; Seki, E.; Harismendy, O.; Shalapour, S.; Karin, M.; et al. Integrative genomic analysis of mouse and human hepatocellular carcinoma. Proc. Natl. Acad. Sci. USA 2018, 115, E9879-E9888. [CrossRef]

39. Corpet, D.E.; Pierre, F. How good are rodent models of carcinogenesis in predicting efficacy in humans? A systematic review and meta-analysis of colon chemoprevention in rats, mice and men. Eur. J. Cancer 2005, 41, 1911-1922. [CrossRef]

40. Scheffer, S.R.; Nave, H.; Korangy, F.; Schlote, K.; Pabst, R.; Jaffee, E.M.; Manns, M.P.; Greten, T.F. Apoptotic, but not necrotic, tumor cell vaccines induce a potent immune response in vivo. Int. J. Cancer 2003, 103, 205-211. [CrossRef]

41. Kroemer, G.; Galluzzi, L.; Kepp, O.; Zitvogel, L. Immunogenic cell death in cancer therapy. Annu. Rev. Immunol. 2013, 31, 51-72. [CrossRef]

42. Wissniowski, T.T.; Hansler, J.; Neureiter, D.; Frieser, M.; Schaber, S.; Esslinger, B.; Voll, R.; Strobel, D.; Hahn, E.G.; Schuppan, D. Activation of tumor-specific T lymphocytes by radio-frequency ablation of the VX2 hepatoma in rabbits. Cancer Res. 2003, 63, 6496-6500.

43. den Brok, M.H.; Sutmuller, R.P.; Nierkens, S.; Bennink, E.J.; Frielink, C.; Toonen, L.W.; Boerman, O.C.; Figdor, C.G.; Ruers, T.J.; Adema, G.J. Efficient loading of dendritic cells following cryo and radiofrequency ablation in combination with immune modulation induces anti-tumour immunity. Br. J. Cancer 2006, 95, 896-905. [CrossRef]

44. Dromi, S.A.; Walsh, M.P.; Herby, S.; Traughber, B.; Xie, J.; Sharma, K.V.; Sekhar, K.P.; Luk, A.; Liewehr, D.J.; Dreher, M.R.; et al. Radiofrequency ablation induces antigen-presenting cell infiltration and amplification of weak tumor-induced immunity. Radiology 2009, 251, 58-66. [CrossRef]

45. den Brok, M.H.; Sutmuller, R.P.; van der Voort, R.; Bennink, E.J.; Figdor, C.G.; Ruers, T.J.; Adema, G.J. In situ tumor ablation creates an antigen source for the generation of antitumor immunity. Cancer Res 2004, 64, 4024-4029. [CrossRef]

46. Waitz, R.; Solomon, S.B.; Petre, E.N.; Trumble, A.E.; Fasso, M.; Norton, L.; Allison, J.P. Potent induction of tumor immunity by combining tumor cryoablation with anti-CTLA-4 therapy. Cancer Res. 2012, 72, 430-439. [CrossRef]

47. Behm, B.; Di Fazio, P.; Michl, P.; Neureiter, D.; Kemmerling, R.; Hahn, E.G.; Strobel, D.; Gress, T.; Schuppan, D.; Wissniowski, T.T. Additive antitumour response to the rabbit VX2 hepatoma by combined radio frequency ablation and toll like receptor 9 stimulation. Gut 2016, 65, 134-143. [CrossRef] [PubMed]

48. Zhou, Y.; Xu, X.; Ding, J.; Jing, X.; Wang, F.; Wang, Y.; Wang, P. Dynamic changes of T-cell subsets and their relation with tumor recurrence after microwave ablation in patients with hepatocellular carcinoma. J. Cancer Res. Ther. 2018, 14, 40-45. [CrossRef]

49. Zhang, H.; Hou, X.; Cai, H.; Zhuang, X. Effects of microwave ablation on T-cell subsets and cytokines of patients with hepatocellular carcinoma. Minim. Invasive Ther. Allied Technol. 2017, 26, 207-211. [CrossRef] [PubMed]

50. Zerbini, A.; Pilli, M.; Fagnoni, F.; Pelosi, G.; Pizzi, M.G.; Schivazappa, S.; Laccabue, D.; Cavallo, C.; Schianchi, C.; Ferrari, C.; et al. Increased immunostimulatory activity conferred to antigen-presenting cells by exposure to antigen extract from hepatocellular carcinoma after radiofrequency thermal ablation. J. Immunother. 2008, 31, 271-282. [CrossRef]

51. Mizukoshi, E.; Yamashita, T.; Arai, K.; Sunagozaka, H.; Ueda, T.; Arihara, F.; Kagaya, T.; Yamashita, T.; Fushimi, K.; Kaneko, $\mathrm{S}$. Enhancement of tumor-associated antigen-specific $\mathrm{T}$ cell responses by radiofrequency ablation of hepatocellular carcinoma. Hepatology 2013, 57, 1448-1457. [CrossRef] 
52. Arihara, F.; Mizukoshi, E.; Kitahara, M.; Takata, Y.; Arai, K.; Yamashita, T.; Nakamoto, Y.; Kaneko, S. Increase in CD14+HLA-DR -/low myeloid-derived suppressor cells in hepatocellular carcinoma patients and its impact on prognosis. Cancer Immunol. Immunother. 2013, 62, 1421-1430. [CrossRef]

53. Nobuoka, D.; Motomura, Y.; Shirakawa, H.; Yoshikawa, T.; Kuronuma, T.; Takahashi, M.; Nakachi, K.; Ishii, H.; Furuse, J.; Gotohda, N.; et al. Radiofrequency ablation for hepatocellular carcinoma induces glypican-3 peptide-specific cytotoxic $\mathrm{T}$ lymphocytes. Int. J. Oncol. 2012, 40, 63-70. [CrossRef] [PubMed]

54. Kim, M.J.; Jang, J.W.; Oh, B.S.; Kwon, J.H.; Chung, K.W.; Jung, H.S.; Jekarl, D.W.; Lee, S. Change in inflammatory cytokine profiles after transarterial chemotherapy in patients with hepatocellular carcinoma. Cytokine 2013, 64, 516-522. [CrossRef] [PubMed]

55. Liao, J.; Xiao, J.; Zhou, Y.; Liu, Z.; Wang, C. Effect of transcatheter arterial chemoembolization on cellular immune function and regulatory $\mathrm{T}$ cells in patients with hepatocellular carcinoma. Mol. Med. Rep. 2015, 12, 6065-6071. [CrossRef]

56. Chew, V.; Lee, Y.H.; Pan, L.; Nasir, N.J.M.; Lim, C.J.; Chua, C.; Lai, L.; Hazirah, S.N.; Lim, T.K.H.; Goh, B.K.P.; et al. Immune activation underlies a sustained clinical response to Yttrium-90 radioembolisation in hepatocellular carcinoma. Gut 2019, 68, 335-346. [CrossRef]

57. Duffy, A.G.; Ulahannan, S.V.; Makorova-Rusher, O.; Rahma, O.; Wedemeyer, H.; Pratt, D.; Davis, J.L.; Hughes, M.S.; Heller, T.; ElGindi, M.; et al. Tremelimumab in combination with ablation in patients with advanced hepatocellular carcinoma. J. Hepatol. 2017, 66, 545-551. [CrossRef] [PubMed]

58. Galon, J.; Bruni, D. Approaches to treat immune hot, altered and cold tumours with combination immunotherapies. Nat. Rev. Drug Discov. 2019, 18, 197-218. [CrossRef] [PubMed]

59. McGrail, D.J.; Pilie, P.G.; Rashid, N.U.; Voorwerk, L.; Slagter, M.; Kok, M.; Jonasch, E.; Khasraw, M.; Heimberger, A.B.; Lim, B.; et al. High tumor mutation burden fails to predict immune checkpoint blockade response across all cancer types. Ann. Oncol. 2021. [CrossRef] [PubMed]

60. Feng, G.S.; Hanley, K.L.; Liang, Y.; Lin, X. Improving the efficacy of liver cancer immunotherapy: The power of combined preclinical and clinical studies. Hepatology 2021, 73 (Suppl. 1), 104-114. [CrossRef]

61. The Cancer Genome Atlas Research Network. Comprehensive and integrative genomic characterization of hepatocellular carcinoma. Cell 2017, 169, 1327-1341.e23. [CrossRef]

62. Ringelhan, M.; Pfister, D.; O'Connor, T.; Pikarsky, E.; Heikenwalder, M. The immunology of hepatocellular carcinoma. Nat. Immunol. 2018, 19, 222-232. [CrossRef]

63. Jenne, C.N.; Kubes, P. Immune surveillance by the liver. Nat. Immunol. 2013, 14, 996-1006. [CrossRef] [PubMed]

64. Zhou, G.; Sprengers, D.; Boor, P.P.C.; Doukas, M.; Schutz, H.; Mancham, S.; Pedroza-Gonzalez, A.; Polak, W.G.; de Jonge, J.; Gaspersz, M.; et al. Antibodies against immune checkpoint molecules restore functions of tumor-infiltrating $t$ cells in hepatocellular carcinomas. Gastroenterology 2017, 153, 1107-1119.e10. [CrossRef] [PubMed]

65. Neureiter, D.; Stintzing, S.; Kiesslich, T.; Ocker, M. Hepatocellular carcinoma: Therapeutic advances in signaling, epigenetic and immune targets. World J. Gastroenterol. 2019, 25, 3136-3150. [CrossRef] [PubMed]

66. Yu, J.; Green, M.D.; Li, S.; Sun, Y.; Journey, S.N.; Choi, J.E.; Rizvi, S.M.; Qin, A.; Waninger, J.J.; Lang, X.; et al. Liver metastasis restrains immunotherapy efficacy via macrophage-mediated T cell elimination. Nat. Med. 2021. [CrossRef]

67. Liu, F.; Liu, Y.; Chen, Z. Tim-3 expression and its role in hepatocellular carcinoma. J. Hematol. Oncol. 2018, 11, 126. [CrossRef]

68. Acharya, N.; Sabatos-Peyton, C.; Anderson, A.C. Tim-3 finds its place in the cancer immunotherapy landscape. J. Immunother. Cancer 2020, 8. [CrossRef]

69. Yan, W.; Liu, X.; Ma, H.; Zhang, H.; Song, X.; Gao, L.; Liang, X.; Ma, C. Tim-3 fosters HCC development by enhancing TGF-beta-mediated alternative activation of macrophages. Gut 2015, 64, 1593-1604. [CrossRef]

70. Zahran, A.M.; Hetta, H.F.; Rayan, A.; Eldin, A.S.; Hassan, E.A.; Fakhry, H.; Soliman, A.; El-Badawy, O. Differential expression of Tim-3, PD-1, and CCR5 on peripheral T and B lymphocytes in hepatitis C virus-related hepatocellular carcinoma and their impact on treatment outcomes. Cancer Immunol. Immunother. 2020, 69, 1253-1263. [CrossRef]

71. Tampaki, M.; Ionas, E.; Hadziyannis, E.; Deutsch, M.; Malagari, K.; Koskinas, J. Association of TIM-3 with BCLC stage, serum PD-L1 detection, and response to transarterial chemoembolization in patients with hepatocellular carcinoma. Cancers 2020, 12, 212. [CrossRef]

72. Li, H.; Wu, K.; Tao, K.; Chen, L.; Zheng, Q.; Lu, X.; Liu, J.; Shi, L.; Liu, C.; Wang, G.; et al. Tim-3/galectin-9 signaling pathway mediates T-cell dysfunction and predicts poor prognosis in patients with hepatitis B virus-associated hepatocellular carcinoma. Hepatology 2012, 56, 1342-1351. [CrossRef]

73. Wolf, Y.; Anderson, A.C.; Kuchroo, V.K. TIM3 comes of age as an inhibitory receptor. Nat. Rev. Immunol. 2020, 20, 173-185. [CrossRef]

74. Fujita, K.; Iwama, H.; Sakamoto, T.; Okura, R.; Kobayashi, K.; Takano, J.; Katsura, A.; Tatsuta, M.; Maeda, E.; Mimura, S.; et al. Galectin-9 suppresses the growth of hepatocellular carcinoma via apoptosis in vitro and in vivo. Int. J. Oncol. 2015, 46, 2419-2430. [CrossRef] [PubMed]

75. Fujita, K.; Niki, T.; Nomura, T.; Oura, K.; Tadokoro, T.; Sakamoto, T.; Tani, J.; Yoneyama, H.; Morishita, A.; Kuroda, N.; et al. Correlation between serum galectin-9 levels and liver fibrosis. J. Gastroenterol. Hepatol. 2018, 33, 492-499. [CrossRef] [PubMed]

76. Lecocq, Q.; Keyaerts, M.; Devoogdt, N.; Breckpot, K. The next-generation immune checkpoint LAG-3 and its therapeutic potential in oncology: Third time's a charm. Int. J. Mol. Sci. 2020, 22, 75. [CrossRef]

77. Joller, N.; Kuchroo, V.K. Tim-3, Lag-3, and TIGIT. Curr. Top. Microbiol. Immunol. 2017, 410, 127-156. [CrossRef] 
78. Johnson, D.B.; Nixon, M.J.; Wang, Y.; Wang, D.Y.; Castellanos, E.; Estrada, M.V.; Ericsson-Gonzalez, P.I.; Cote, C.H.; Salgado, R.; Sanchez, V.; et al. Tumor-specific MHC-II expression drives a unique pattern of resistance to immunotherapy via LAG-3/FCRL6 engagement. JCI Insight 2018, 3. [CrossRef]

79. Stecher, C.; Battin, C.; Leitner, J.; Zettl, M.; Grabmeier-Pfistershammer, K.; Holler, C.; Zlabinger, G.J.; Steinberger, P. PD-1 blockade promotes emerging checkpoint inhibitors in enhancing T cell responses to allogeneic dendritic cells. Front. Immunol. $2017,8,572$. [CrossRef]

80. Huang, R.Y.; Francois, A.; McGray, A.R.; Miliotto, A.; Odunsi, K. Compensatory upregulation of PD-1, LAG-3, and CTLA-4 limits the efficacy of single-agent checkpoint blockade in metastatic ovarian cancer. Oncoimmunology 2017, 6, e1249561. [CrossRef]

81. Huard, B.; Mastrangeli, R.; Prigent, P.; Bruniquel, D.; Donini, S.; El-Tayar, N.; Maigret, B.; Dreano, M.; Triebel, F. Characterization of the major histocompatibility complex class II binding site on LAG-3 protein. Proc. Natl. Acad. Sci. USA 1997, 94, 5744-5749. [CrossRef]

82. Xu, F.; Liu, J.; Liu, D.; Liu, B.; Wang, M.; Hu, Z.; Du, X.; Tang, L.; He, F. LSECtin expressed on melanoma cells promotes tumor progression by inhibiting antitumor T-cell responses. Cancer Res. 2014, 74, 3418-3428. [CrossRef]

83. Kouo, T.; Huang, L.; Pucsek, A.B.; Cao, M.; Solt, S.; Armstrong, T.; Jaffee, E. Galectin-3 shapes antitumor immune responses by suppressing CD8+ T Cells via LAG-3 and inhibiting expansion of plasmacytoid dendritic cells. Cancer Immunol. Res. 2015, 3, 412-423. [CrossRef]

84. Wang, J.; Sanmamed, M.F.; Datar, I.; Su, T.T.; Ji, L.; Sun, J.; Chen, L.; Chen, Y.; Zhu, G.; Yin, W.; et al. Fibrinogen-like protein 1 is a major immune inhibitory ligand of LAG-3. Cell 2019, 176, 334-347.e12. [CrossRef]

85. Dhar, D.; Baglieri, J.; Kisseleva, T.; Brenner, D.A. Mechanisms of liver fibrosis and its role in liver cancer. Exp. Biol. Med. (Maywood) 2020, 245, 96-108. [CrossRef]

86. Feng, Y.X.; Li, W.; Wen, X.D.; Zhang, N.; Liu, W.H.; Yang, Z.Y. Sinusoidal endothelial cell progenitor cells promote tumour progression in patients with hepatocellular carcinoma. Stem Cells Int. 2020, 2020, 8819523. [CrossRef]

87. Song, M.; Pan, Q.; Yang, J.; He, J.; Zeng, J.; Cheng, S.; Huang, Y.; Zhou, Z.Q.; Zhu, Q.; Yang, C.; et al. Galectin-3 favours tumour metastasis via the activation of beta-catenin signalling in hepatocellular carcinoma. Br. J. Cancer 2020, 123, 1521-1534. [CrossRef]

88. Serizawa, N.; Tian, J.; Fukada, H.; Baghy, K.; Scott, F.; Chen, X.; Kiss, Z.; Olson, K.; Hsu, D.; Liu, F.T.; et al. Galectin 3 regulates HCC cell invasion by RhoA and MLCK activation. Lab. Invest. 2015, 95, 1145-1156. [CrossRef]

89. Sayeed, A.; Dalvano, B.E.; Kaplan, D.E.; Viswanathan, U.; Kulp, J.; Janneh, A.H.; Hwang, L.Y.; Ertel, A.; Doria, C.; Block, T. Profiling the circulating mRNA transcriptome in human liver disease. Oncotarget 2020, 11, 2216-2232. [CrossRef]

90. Guo, M.; Yuan, F.; Qi, F.; Sun, J.; Rao, Q.; Zhao, Z.; Huang, P.; Fang, T.; Yang, B.; Xia, J. Expression and clinical significance of LAG-3, FGL1, PD-L1 and CD8(+)T cells in hepatocellular carcinoma using multiplex quantitative analysis. J. Transl. Med. 2020, 18, 306. [CrossRef]

91. Li, F.J.; Zhang, Y.; Jin, G.X.; Yao, L.; Wu, D.Q. Expression of LAG-3 is coincident with the impaired effector function of HBV-specific CD8(+) T cell in HCC patients. Immunol. Lett. 2013, 150, 116-122. [CrossRef]

92. Woo, S.R.; Turnis, M.E.; Goldberg, M.V.; Bankoti, J.; Selby, M.; Nirschl, C.J.; Bettini, M.L.; Gravano, D.M.; Vogel, P.; Liu, C.L.; et al. Immune inhibitory molecules LAG-3 and PD-1 synergistically regulate T-cell function to promote tumoral immune escape. Cancer Res. 2012, 72, 917-927. [CrossRef] [PubMed]

93. Matsuzaki, J.; Gnjatic, S.; Mhawech-Fauceglia, P.; Beck, A.; Miller, A.; Tsuji, T.; Eppolito, C.; Qian, F.; Lele, S.; Shrikant, P.; et al. Tumor-infiltrating NY-ESO-1-specific CD8+ T cells are negatively regulated by LAG-3 and PD-1 in human ovarian cancer. Proc. Natl. Acad. Sci. USA 2010, 107, 7875-7880. [CrossRef] [PubMed]

94. Huang, R.Y.; Eppolito, C.; Lele, S.; Shrikant, P.; Matsuzaki, J.; Odunsi, K. LAG3 and PD1 co-inhibitory molecules collaborate to limit CD8+ T cell signaling and dampen antitumor immunity in a murine ovarian cancer model. Oncotarget 2015, 6, 27359-27377. [CrossRef]

95. Burova, E.; Hermann, A.; Dai, J.; Ullman, E.; Halasz, G.; Potocky, T.; Hong, S.; Liu, M.; Allbritton, O.; Woodruff, A.; et al. Preclinical development of the anti-LAG-3 antibody REGN3767: Characterization and activity in combination with the anti-PD-1 antibody cemiplimab in human PD-1xLAG-3-knockin mice. Mol. Cancer Ther. 2019, 18, 2051-2062. [CrossRef]

96. Harjunpaa, H.; Guillerey, C. TIGIT as an emerging immune checkpoint. Clin. Exp. Immunol. 2020, 200, 108-119. [CrossRef] [PubMed]

97. Okwor, C.I.A.; Oh, J.S.; Crawley, A.M.; Cooper, C.L.; Lee, S.H. Expression of inhibitory receptors on T and NK cells defines immunological phenotypes of HCV patients with advanced liver fibrosis. iScience 2020, 23, 101513. [CrossRef]

98. Liu, X.; Li, M.; Wang, X.; Dang, Z.; Jiang, Y.; Wang, X.; Kong, Y.; Yang, Z. PD-1(+) TIGIT(+) CD8(+) T cells are associated with pathogenesis and progression of patients with hepatitis B virus-related hepatocellular carcinoma. Cancer Immunol. Immunother. 2019, 68, 2041-2054. [CrossRef]

99. Zhang, C.; Wang, Y.; Xun, X.; Wang, S.; Xiang, X.; Hu, S.; Cheng, Q.; Guo, J.; Li, Z.; Zhu, J. TIGIT can exert immunosuppressive effects on CD8+ T cells by the CD155/TIGIT Signaling pathway for hepatocellular carcinoma in vitro. J. Immunother. 2020, 43, 236-243. [CrossRef]

100. Chiu, D.K.; Yuen, V.W.; Cheu, J.W.; Wei, L.L.; Ting, V.; Fehlings, M.; Sumatoh, H.; Nardin, A.; Newell, E.W.; Ng, I.O.; et al. Hepatocellular carcinoma cells up-regulate PVRL1, stabilizing PVR and inhibiting the cytotoxic T-cell response via TIGIT to mediate tumor resistance to PD1 inhibitors in mice. Gastroenterology 2020, 159, 609-623. [CrossRef] 
101. Duan, X.; Liu, J.; Cui, J.; Ma, B.; Zhou, Q.; Yang, X.; Lu, Z.; Du, Y.; Su, C. Expression of TIGIT/CD155 and correlations with clinical pathological features in human hepatocellular carcinoma. Mol. Med. Rep. 2019, 20, 3773-3781. [CrossRef]

102. Rodriguez-Abreu, D.; Johnson, M.L.; Hussein, M.A.; Cobo, M.; Patel, A.J.; Secen, N.M.; Lee, K.H.; Massuti, B.; Hiret, S.; Yang, J.C.-H.; et al. Primary analysis of a randomized, double-blind, phase II study of the anti-TIGIT antibody tiragolumab (tira) plus atezolizumab (atezo) versus placebo plus atezo as first-line (1L) treatment in patients with PD-L1-selected NSCLC (CITYSCAPE). J. Clin. Oncol. 2020, 38, 9503. [CrossRef]

103. Hu, Y.; Zeng, T.; Xiao, Z.; Hu, Q.; Li, Y.; Tan, X.; Yue, H.; Wang, W.; Tan, H.; Zou, J. Immunological role and underlying mechanisms of B7-H6 in tumorigenesis. Clin. Chim. Acta 2020, 502, 191-198. [CrossRef]

104. Brandt, C.S.; Baratin, M.; Yi, E.C.; Kennedy, J.; Gao, Z.; Fox, B.; Haldeman, B.; Ostrander, C.D.; Kaifu, T.; Chabannon, C.; et al. The B7 family member B7-H6 is a tumor cell ligand for the activating natural killer cell receptor NKp30 in humans. J. Exp. Med. 2009, 206, 1495-1503. [CrossRef]

105. Wu, F.; Wang, J.; Ke, X. Knockdown of B7-H6 inhibits tumor progression and enhances chemosensitivity in B-cell non-Hodgkin lymphoma. Int. J. Oncol. 2016, 48, 1561-1570. [CrossRef]

106. Li, Y.M.; Liu, Z.Y.; Li, Z.C.; Wang, J.C.; Yu, J.M.; Yang, H.J.; Chen, Z.N.; Tang, J. Alterations of the immunologic co-stimulator B7 and TNFR families correlate with hepatocellular carcinoma prognosis and metastasis by inactivating STAT3. Int. J. Mol. Sci. 2019, 20, 156. [CrossRef] [PubMed]

107. Zhang, X.; Xie, W.; Wang, Z.; Song, S.; Qin, Y.; Zhang, F.; Chen, F.; Cai, L. Expression of a novel immune checkpoint B7-H6 ligand in human small cell lung cancer. Ann. Transl. Med. 2020, 8, 589. [CrossRef]

108. Zhou, H.; Dong, J.; Guo, L.; Wang, X.; Wang, K.; Cai, X.; Yang, S. The prognostic value of B7-H6 in esophageal squamous cell carcinoma. Sci. Rep. 2019, 9, 18122. [CrossRef] [PubMed]

109. Jiang, T.; Wu, W.; Zhang, H.; Zhang, X.; Zhang, D.; Wang, Q.; Huang, L.; Wang, Y.; Hang, C. High expression of B7-H6 in human glioma tissues promotes tumor progression. Oncotarget 2017, 8, 37435-37447. [CrossRef] [PubMed]

110. Zhou, Y.; Xu, Y.; Chen, L.; Xu, B.; Wu, C.; Jiang, J. B7-H6 expression correlates with cancer progression and patient's survival in human ovarian cancer. Int. J. Clin. Exp. Pathol. 2015, 8, 9428-9433.

111. Chen, L.; Feng, J.; Xu, B.; Zhou, Y.; Zheng, X.; Wu, C.; Jiang, J. B7-H6 expression in human hepatocellular carcinoma and its clinical significance. Cancer Cell Int. 2018, 18, 126. [CrossRef] [PubMed]

112. Pinheiro, P.F.; Justino, G.C.; Marques, M.M. NKp30-A prospective target for new cancer immunotherapy strategies. Br. J. Pharmacol. 2020, 177, 4563-4580. [CrossRef] [PubMed]

113. Feng, M.; Jiang, W.; Kim, B.Y.S.; Zhang, C.C.; Fu, Y.X.; Weissman, I.L. Phagocytosis checkpoints as new targets for cancer immunotherapy. Nat. Rev. Cancer 2019, 19, 568-586. [CrossRef]

114. Catalan, R.; Orozco-Morales, M.; Hernandez-Pedro, N.Y.; Guijosa, A.; Colin-Gonzalez, A.L.; Avila-Moreno, F.; Arrieta, O. CD47-SIRPalpha axis as a biomarker and therapeutic target in cancer: Current perspectives and future challenges in nonsmall cell lung cancer. J. Immunol. Res. 2020, 2020, 9435030. [CrossRef]

115. Lo, J.; Lau, E.Y.; So, F.T.; Lu, P.; Chan, V.S.; Cheung, V.C.; Ching, R.H.; Cheng, B.Y.; Ma, M.K.; Ng, I.O.; et al. Anti-CD47 antibody suppresses tumour growth and augments the effect of chemotherapy treatment in hepatocellular carcinoma. Liver Int. 2016, 36, 737-745. [CrossRef]

116. Leclair, P.; Lim, C.J. CD47 (Cluster of differentiation 47): An anti-phagocytic receptor with a multitude of signaling functions. Anim. Cells Syst. (Seoul) 2020, 24, 243-252. [CrossRef]

117. Yu, W.B.; Ye, Z.H.; Chen, X.; Shi, J.J.; Lu, J.J. The development of small-molecule inhibitors targeting CD47. Drug Discov. Today 2020. [CrossRef]

118. Li, T.; Fu, J.; Zeng, Z.; Cohen, D.; Li, J.; Chen, Q.; Li, B.; Liu, X.S. TIMER2.0 for analysis of tumor-infiltrating immune cells. Nucleic Acids Res. 2020, 48, W509-W514. [CrossRef]

119. Zhang, X.; El-Serag, H.B.; Thrift, A.P. Predictors of five-year survival among patients with hepatocellular carcinoma in the United States: An analysis of SEER-Medicare. Cancer Causes Control. 2021. [CrossRef] 